\title{
Kajian Kerusakan Lahan Di Daerah Aliran Sungai (DAS) Kreo Akibat Pembangunan Pemukiman Di Sekitar Waduk Jatibarang Kota Semarang
}

\author{
Wahyu Setyaningsih, Sriyono dan Andi Irwan Benardi
}

Masuk: 04102018 / Diterima: 28112018 / Dipublikasi: 31122018

(c) 2018 Fakultas Hukum dan IImu Sosial UNDIKSHA dan IGI

\begin{abstract}
Increasing demand for land causes human expansion into green areas to conduct settlement development. The development activity will have an impact on land damage in the Kreo watershed area of Semarang City. The purpose of this research are: (1) Knowing the impact of land damage Kreo Watershed because of development the Jatibarang Reservoir; (2) Knowing how to conserve land in the watershed so as not damaged Kreo. The research methods conducted by survey method. The research location is Watershed Kreo Semarang city and surrounding. Data collection technique are including observation, field measurement, documentation, mapping of geographic information system. Techniques analysis are spasial analysis based on geographic information system, descriptive quantitative, and analysis with cross table. The result of the research show that level of damaged land which exist in Watershed Kreo include in the high criteria. This is caused by geophysic land condition for example angle of slope, geology, land, land utility, and high rain season.
\end{abstract}

Keywords: Land Degradation; Geophysical Land; Kreo Wathershed

Abstrak Bertambahnya kebutuhan akan lahan menyebabkan ekspansi manusia ke area-area hijau untuk melakukan pembangunan pemukiman. Kegiatan pembangunan tersebut akan memberikan dampak terhadap kerusakan lahan di wilayah DAS Kreo Kota Semarang. Tujuan penelitian ini adalah: (1) Untuk mengetahui dampak pembangunan pemukiman di sekitar kota Semarang kerusakan lahan DAS Kreo; (2) Mengetahui cara mengkonservasi lahan di DAS Kreo supaya tidak rusak. Metode penelitian dilakukan metode survei. Lokasi penelitian dilakukan di DAS Kreo Kota Semarang dan sekitarnya. Teknik pengumpulan data observasi, pengukuran lapangan, dokumentasi, pemetaan sistem informasi geografis. Teknik analisis data analisis spasial berbasis SIG, analisis deskriptif kuantitatif, dan analisis metode tabel silang. Hasil penelitian menunjukkan bahwa tingkat kerusakan lahan yang ada di DAS Kreo termasuk dalam kriteria tinggi. Hal ini disebabkan karena pembangunan Waduk Jatibarang selain itu juga faktor geofisik seperti kemiringan lereng, geologi, tanah, penggunaan lahan, dan curah hujan yang tinggi.

Kata kunci: Kerusakan Lahan; Geofisik Lahan; DAS Kreo

\section{Pendahuluan}

Lahan (land) merupakan suatu wilayah di permukaan bumi, mencakup semua komponen biosfer yang dapat dianggap tetap atau bersifat siklis yang berada di atas dan di bawah wilayah tersebut, termasuk atmosfer, tanah, batuan induk, relief, hidrologi, tumbuhan dan hewan, serta segala akibat yang ditimbulkan oleh aktivitas manusia di masa lalu dan sekarang yang kesemuanya itu berpengaruh terhadap

Wahyu Setyaningsih, Sriyono dan Andi Irwan Benardi Fakultas IImu Sosial Universitas Negeri Semarang neni.wahyuningtyas.fis@um.ac.id penggunaan lahan oleh manusia pada saat sekarang dan di masa akan datang (Brinkman dan Smyth, 1973; Vink, 1975; dan FAO, 1976).

Kerusakan lahan atau tanah dapat menyebabkan berbagai dampak antara lain terjadinya erosi dan sedimentasi serta masih banyak hal yang ditimbulkan. Erosi mempunyai beberapa akibat buruk. Kedua menurunnya produksi sehingga akan mengurangi pendapatan petani. Erosi tanah dapat terjadi akibat adanya curah hujan yang tinggi, Vegetasi penutup lahan yang kurang, kemiringan lereng dan tata guna lahan yang kurang tepat. 
Berkurangnya luasan hutan menyebabkan terjadinya kerusakan lahan dan penurunan produktivitas tanah. Perubahan hutan menjadi lahan pertanian sangat memungkinkan terjadinya penurunan kondisi kesuburan tanah dan sifat fisik tanah. Kawasan perbukitanpegunungan di DAS Kreo mengalami kerusakan lingkungan, terutama sumber daya lahan dan air. Faktor yang memicu penurunan kondisi lingkungan tersebut diantaranya adalah cara petani memperlakukan lahan/tanah, karakteristik geofisik lahan, curah hujan yang tinggi serta ekstensifikasi lahan pertanian pada lahan kawasan lindung.

Di dalam DAS Kreo kini sedang berlangsung pembangunan proyek Waduk Jatibarang. Waduk Jaribarang wilayahnya meliputi empat kelurahan antara lain Jatibarang, Jatirejo, Kedungpane, dan Kandri. Serta di dua wilayah kecamatan, yakni Kecamatan Mijen dan Gunungpati yang berfungsi sebagai pengelolaan sumber daya air dan pengendalian banjir secara terpadu dan serbaguna.

Oleh karena itu, maka peneliti tertarik melakukan penelitian dengan judul "Kajian Kerusakan Lahan Di DAS Kreo Akibat Pembangunan pemukiman di sekitar Kota Semarang". Tujuan penelitian: 1) Untuk mengetahui perubahan penggunaan lahan di DAS Kreo. 2) Untuk mengetahui kerusakan lahan di sekitar lahan DAS Kreo Akibat pembangunan pemukiman di sekitar waduk Jatibarang.

\section{Metode}

Metode penelitian dilakukan metode survei dan random sampling. Lokasi penelitian dilakukan di DAS Kreo
Kota Semarang dan sekitarnya. Variabel dalam penelitian ini meliputi tipe satuan bentuklahan, perubahan pemanfaatan lahan. Metode pengumpulan data yang digunakan adalah observasi, dokumentasi, pemetaan sistem informasi geografis. Teknik analisis data yang digunakan dalam penelitian ini adalah analisis spasial berbasis sistem informasi geografis (SIG), analisis deskriptif.

Populasi penelitian ini adalah kondisi penggunaan lahan di daerah DAS Kreo. Pengukuran kondisi geofisik lahan dilakukan dengan systematic random sampling, metode sampling dalam penelitian ini digunakan karena pertimbangan wilayah penelitian yang cukup luas yaitu $68,56 \mathrm{Km} 2$. Pengambilan sampel geofisik lahan terdiri atas kedalaman efektif tanah, sebaran batuan lepas, tingkat kerapatan alur, dan penutup lahan yang diperoleh dari setiap satuan bentuklahan. Kedalaman efektif tanah diambil dengan teknik pengeboran tanah; sebaran batuan lepas diperoleh dengan teknik pengukuran kotak bercak. Variabel dalam penelitian ini meliputi tipe satuan bentuklahan, kerusakan lahan potensial, kerusakan lahan aktual, dan tipologi pemanfaatan lahan. Metode pengumpulan data yang digunakan adalah observasi, pengukuran lapangan, dokumentasi, pemetaan sistem informasi geografis. Teknik analisis data yang digunakan dalam penelitian ini adalah analisis spasial berbasis sistem informasi geografis (SIG), analisis deskriptif kuantitatif, analisis tabel silang. 


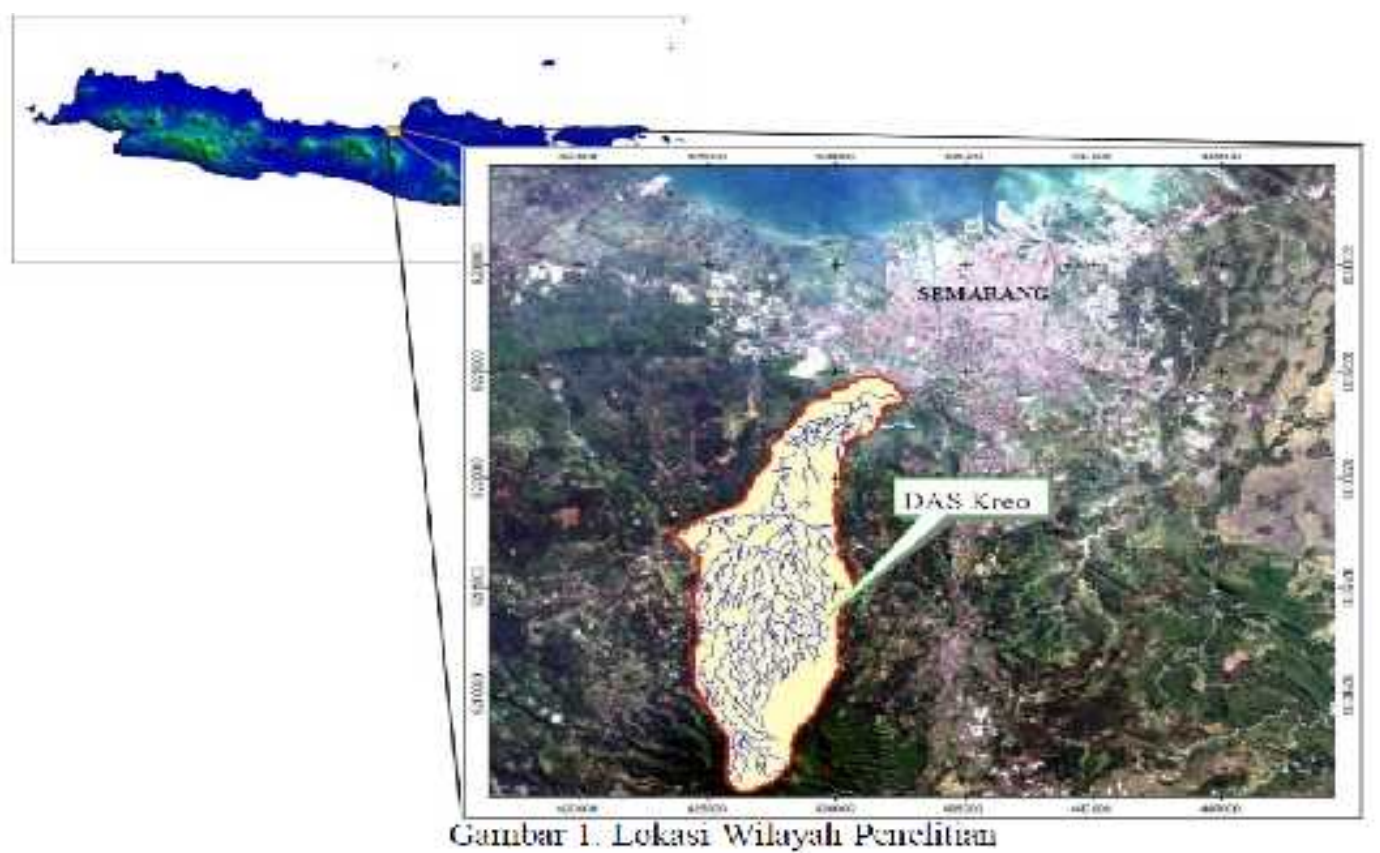

\section{Hasil dan Pembahasan}

\section{Gambaran Umum Lokasi Penelitian}

Daerah penelitian terletak di DAS

Kreo yang merupakan bagian dari DAS Garang dengan luas lahan 6.856,27 $\mathrm{Ha}$.

DAS Garang ini terdiri dari empat sub DAS yaitu sub DAS Garang Hulu, sub DAS Kreo, sub DAS Kripik, dan sub DAS Garang Hilir dan Banjir Kanal Barat. Sub DAS Kreo terletak antara 110 o 18' 28" 110 o 22' 35" BT dan 7o 00' 45" - 7o 11' 13" LS (Peta RBI Lembar Boja, Sumowono, Jatingaleh, dan Ungaran barat skala 1:25.000).

Daerah penelitian ini mempunyai dua tipe iklim, yakni tipe A (sangat basah) dan B (basah). Kondisi iklim yang relatif basah diwilayah penelitian berpengaruh terhadap aktifitas petani setempat dalam pemanfaatan lahan utuk pertanian, yaitu disatu sisi aktifitas pertanian lahan kering terus dapat dilakukan, namun disisi lain potensi terjadinya erosi dan longsor relatif tinggi. Curah hujan pada daerah penelitian menurut perhitungan data di Stasiun Gunungpati dan Mijen dari tahun 20092013 memiliki curah hujan lebih dari 100 $\mathrm{mm}$. Data suhu rata-rata pada tahun 2009-2013 di DAS Kreo adalah 27,900C, sedangkan suhu rata-rata tertinggi terdapat pada bulan Januari yaitu sebesar 29,000C, dan suhu rata-rata yang paling rendah yaitu pada bulan maret yaitu 26,920C. DAS Garang terdiri dari empat sub DAS yaitu sub DAS Kreo, sub DAS Kripik, sub DAS Garang Hilir, dan sub DAS Garang Hulu. Secara keseluruhan sistem sungai-sungai yang terdapat di DAS Kreo membentuk pola dendritik.

\section{Perubahan pemanfaatan lahan}

Proses spasial pemanfaatan lahan diwilayah penelitian digunakan dasar kajian peta dari tiga titik waktu yang berbeda, yaitu (1) tahun 1995, (2) tahun 2006, (3) tahun 2018. 
Tabel 1. Perubahan Pemanfaatan Lahan Di Wilayah Penelitian Tahun 1995, 2006, \& 2018

\begin{tabular}{lccccccc}
\hline \multirow{2}{*}{ No } & Jenis & \multicolumn{7}{c}{ Luas (Ha) } \\
\cline { 3 - 8 } & Lahanatan & 1995 & $\%$ & 2016 & $\%$ & 2018 & $\%$ \\
\hline 1 & Kebun Campuran & $2.324,67$ & 33,91 & $3.400,72$ & 49,60 & $3.028,08$ & 44,17 \\
2 & Hutan & $1.283,83$ & 18,72 & 115,76 & 16,92 & $1.041,26$ & 15,19 \\
3 & Permukiman & 734,74 & 10,72 & 738,90 & 10,78 & $1.167,41$ & 17,03 \\
4 & Semak Belukar & 125,53 & 1,83 & 28,90 & 0,42 & 41,74 & 0,61 \\
5 & Sawah & $1.839,82$ & 26,83 & $1.129,76$ & 16,48 & 927,60 & 13,53 \\
6 & Tegalan & 547,68 & 7,99 & 398,23 & 5,81 & 426,22 & 6,22 \\
7 & Waduk & 0,00 & 0,00 & 0,00 & 0,00 & 223,95 & 3,27 \\
\hline & Jumlah & $6.856,27$ & 100,00 & $6.856,27$ & 100.00 & $6.856,27$ & 100,00 \\
\hline
\end{tabular}

Sumber: Peta RBI skala 1:25.000 tahun 1995, 2016, 2018

1) Pemanfaatan lahan tahun 1995

Berdasarkan hasil analisis peta Rupabumi tahun 1995, menunjukkan bahwa wilayah DAS Kreo telah didominasi terutama oleh lahan pertanian dengan menggunakan sawah irigasi, dan sebagian kecil semak belukar dan hutan. Hal tersebut menunjukkan bahwa sebagian pemanfaatan lahan pada tahun 1995 kondisi lingkungan masih didominasi oleh tanaman budidaya. Pemanfaatan untuk kebun mencapai 33,91\% kemudian sawah $26,83 \%$, hutan $18,72 \%$ selanjutnya permukiman $10,72 \%$, tegalan $7,99 \%$ dan semak belukar $1,83 \%$.

2) Pemanfaatan lahan tahun 2016

Pemanfaatan lahan di daerah penelitian tahun 2016 dalam beberapa hal megalami perubahan yang berarti. Jenis kebun campuran mengalami peninggkatan dan menjadi tanaman utama didaerah penelitian menggantikan tanaman sawah. Proses perkembangan pemanfaatan lahan pada tahun 2015 menunjukkan gambaran yang berbeda dengan tahun 1995. Kebun campuran mengalami peningkatan yang signifikan sebesar $49,60 \%$, permukiman menjadi 10,78 dan pemanfaatan lainnya mengalami penurunan luas area yakni sawah menjadi $16,48 \%$, semak belukar $0,42 \%$, tegalan $5,81 \%$, dan hutan $16,92 \%$. Hal ini menunjukkan penurunan luas area.

3) Pemanfaatan lahan tahun 2018

Pemanfaatan lahan untuk pertanian dalam tahun 2018 masih tetap didominasi oleh kebun campuran, dan sawah irigasi sedikit mengalami penurunan jika dibanding dengan titik tahun sebelumnya. Berdasarkan hasil analisis peta pemanfaatan lahan 2018 tampak bahwa pemanfaatan lahan untuk kebun campuran masih menjadi tanaman utama di daerah penelitian, meskipun sedikit mengalami penurunan luas area dibandingkan dengan periode titik tahun sebelumnya yakni menjadi 3.028,08 ha(22,17\%). Permukiman mengalami kenaikan luas area seiring dengan perkembangan penduduk dan peningkatan pembangunan di DAS Kreo. Untuk pemanfaatan lahan yang lainnya juga mengalami penurunan luas area. Semak Belukar mengalami peningkatan luas area menjadi 41,74 (0,61\%). Pada areal persawahan mengalami penurunan menjadi 927,60ha $(13,53 \%)$ sebagai dampak di bangunnya Waduk Jatibarang sehingga beberapa lahan kering dan areal persawahan dapat beralih fungsi menjadi lahan basah, wilayah penelitian yang mengalami penurunan penggunaan lahan yaitu di Desa Kandri, Desa Jatirejo dan Desa Kedungpane. Penggunaan lahan yang berkurang yaitu tegalan, kebun campuran dan sawah, terutama di wilayah sekitar Sub DAS Kreo. 


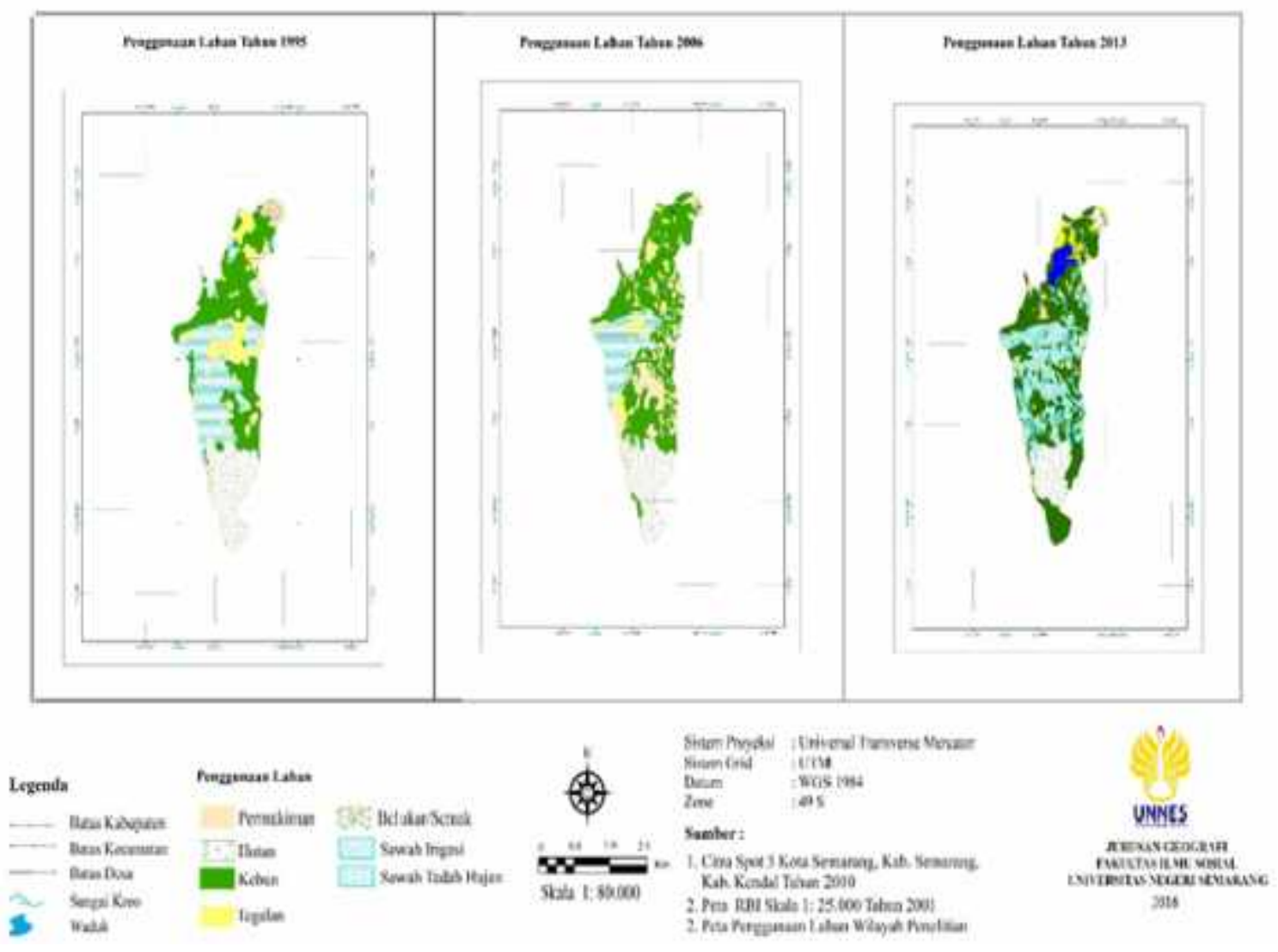

Gambar 2. Peta Perubahan Jenis Pemanfaatan Lahan Daerah Penelitian tahun 1995, 2016 dan 2018

\section{Kerusakan lahan potensial}

Analisis kerusakan lahan potensial di daerah DAS Kreo Kota Semarang dan sekitarnya menunjukan bahwa intensitas kerusakan lahan pada satuan bentuk lahan menunjukan intensitas tinggi hingga sangat tinggi mencapai $50,00 \%$ dari 32 satuan bentuklahan yang telah diteliti.

Intensitas kerusakan lahan potensial yang cukup tinggi di daerah penelitian lebih disebabkan oleh kondisi geofisik lahan, antara lain, kemiringan lereng, geologi, tanah, penggunaan lahan dan curah hujan. Sebaran kerusakan lahan yang ada didaerah penelitian termasuk dalam kriteria sedang. Sebaran kerusakan lahan potensial ini dialami di setiap satuan bentuklahan. Daerah penelitian yang umumnya berpotensi kerusakan sedang tersebar di wilayah daerah hulu DAS.

\section{Kerusakan lahan}

Sebaran spasial kerusakan lahan aktual di daerah penelitian termasuk dalam kategori tinggi.Intensitas kerusakan lahan tinggi berda pada daerah tengah DAS Kreo. Tingkat kerusakan lahan tinggi umumnya tersebar di wilayah Kecamatan Boja dan Mijen. Hal ini karena secara geofisik lahan kedua wilayah tersebut memiliki sifat kerentanan tinggi.

Berdasarkan hasil wawancara dengan informan kunci (Kepala Desa, Kepala Dusun) dan masyarakat sekitar diperoleh kesimpulan bahwa terdapat sejumlaha faktor yang berpengaruh 
terhadap tinggi rendahnya intensitas kerusakan lahan aktual.

1) Kebiasaan petani lokal dalam mengelola lahan pertanian cukup arif, diman lahan yang memiliki kemiringan lereng $8 \%$ digunakan untuk usahatani tanaman musiman, sedangkan lahan yang memiliki kemiringan lereng di atas 10\% dimanfaatkan untuk tanaman tahunan campuran. Selain itu, lahan tidak pernah dibiarkan terbuka.

2) Petani di wilayah DAS Kreo Kota Semaang dan sekitarnya merupakan pemilik dan penggarap dengan luas pemilik lahan 1/2- 1 ha. Lahan tersebut berupa areal permukiman/ pekarangan, tegalan, dan kebun. Tegalan digunakan untuk budidaya tanaman pangan seperti ketela pohon, jagung, dan kacang tanah. Tanaman tahunan yang dominasi yaitu pisang, mlinjo, kelapa, mangga, dan petai, dan kelengkeng, sedangkan tanaman sayuran cabai, tomat, kacang panjang, sawi, dan onclang.

\section{Faktor-faktor yang Berpengaruh terhadap Kerusakan Lahan DAS Kreo Kota Semarang dan Sekitarnya.}

Faktor yang berpengaruh terhadap kerusakan lahan pada wilayah penelitian dapat dibedakan antara faktor alami (geofisik) dan faktor non alami (aktivitas manusia). Faktor alami terutama geofisik lahan yang memiliki sifat kerentanan tinggi terhadap erosi dan longsor lahan. Kondisi topografi yang berbukit bergunung, dengan variasi kemiringan lereng dari datar sampai terjal.

Faktor kerusakan lahan (non alami) akibat campur tangan manusia baik langsung maupun tidak langsung lebih mendominasi dibanding oleh faktor alami yaitu, perubahan populasi, kemiskinan penduduk, masalah kepemilikan lahan dan pengembangan pertanian yang tidak tepat. Penebangan hutan yang terjadi di daerah penelitian yaitu penebangan hutan jati yang terjadi di Desa Gonoharjo. Penebangan secara berlebihan mengakibatkan vegetasi penutup lahan jadi berkurang, penanaman yang selalu berganti, pengembalian yang berlebihan, ketidak seimbangan penggunaan pupuk dan praktek manajemen konservasi lahan yang salah, pemompaan air tanah yang berlebihan adalah beberapa faktor yang disebabkan oleh campur tangan manusia yang mengakibatkan terjadinya erosi tanah. Selain itu juga terdapat pembangunan Waduk Jatibarang yang mengharuskan pelaksanaan pembukaan lahan. Sehingga harus menebang hutan yang seharusnya berfungsi untuk resapan air dan sumber penghidupan bagi makhluk hidup disekitarnya.

\section{Pembahasan}

Hasil penelitian tingkat kerusakan yang ada di DAS Kreo Kota Semarang dan sekitarnya masuk dalam kriteria kritis. Dari empat parameter kerusakan lahan yaitu tingkat kerapatan alur, sebaran batuan lepas, ketebalan tanah, dan vegetasi penutup lahan yang diteliti tingkat kerapatan alur pada setiap satuan bentuk lahan di daerah penelitian menunjukkan tingkat kekritisan yang bervariasai yaitu kritis hingga sedang. Dari 32 satuan bentuklahan yang diteliti 10 satuan bentuk lahan $(40,54 \%)$ berada dalam kriteria sedang dan 22 satuan bentuklahan $(59,46$ $\%)$ berada pada kriteria kritis. Daerah yang masuk pada dalam wilayah kritis umumnya pada satuan bentuklahan dengan formasi batuan andesit. Hal ini karena topografi dari batuan andesit umumnya adalah kasar dengan igir dan lembah yang berlereng terjal sehingga peka terhadap erosi (Sutikno 1989; Sartohadi, 2005 dalam Juhadi, 2013). 


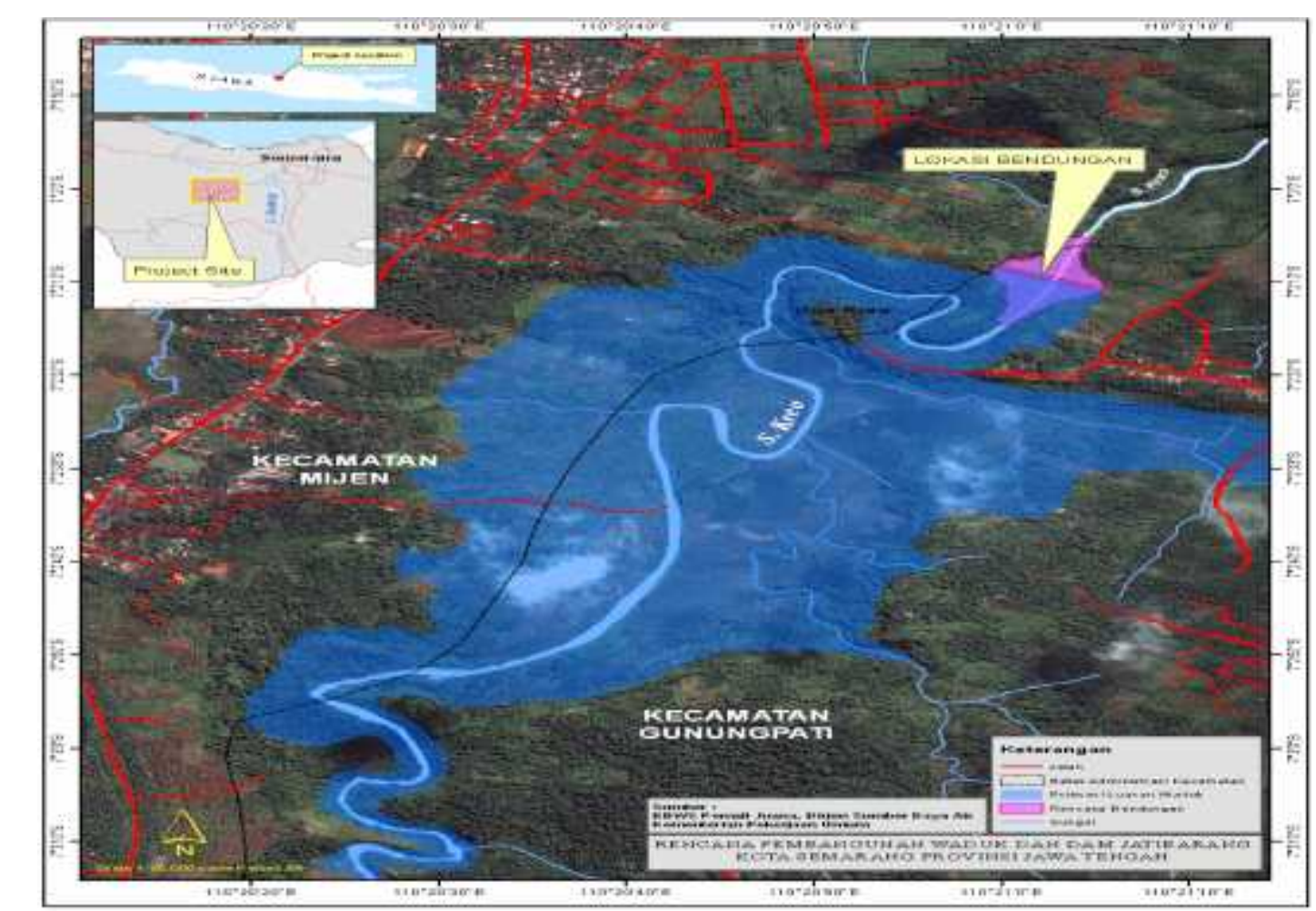

Gambar 3. Peta Perubahan Jenis Pemanfaatan Lahan Daerah Penelitian Rencana Pembuatan Waduk Kreo

Indek kerapatan aliran sungai di DAS Kreo dari seluruh data yang masuk klasifikasi Dd $0,14 \mathrm{~km} / \mathrm{km}^{2}$ (sangat kritis). Bentuk DAS sangat berpengaruh terhadap pola aliran dan ketajaman puncak (discharge) banjir. Bentuk DAS mempengaruhi waktu konsentrasi air hujan yang mengalir menuju outlet. Semakin bulat bentuk DAS berarti semakin singkat waktu konsentrasi yang diperlukan, sehingga semakin tinggi fluktuasi banjir yang terjadi.

Hasil pengamatan di lapangan menunjukkan bahwa terdapat beberapa bentuklahan ketebalan tanah di daerah penelitian rata-rata kurang dari $72 \mathrm{~cm}$. Hal ini karena umumnya merupakan kawasan perbukitan-pegunungan dengan lereng yang terjal. Kondisi lereng yang terjal tersebut berakibat banyak peluang pada tanah tererosi. Oleh karena itu ditinjau dari aspek ketebalan tanah, daerah penelitian termasuk dalam kriteria sedang.
Berdasarkan hasil pengamatan di lapangan, batuan yang ada di daerah penelitian adalah berbatuan sedimen dengan Formasi Damar dan Breksi Vulkanik. Formasi Damar terletak di bagian utara daerah penelitian yang termasuk dalam Kecamatan Semarang Barat. Formasi Damar berbatuan batu pasir tufan, kongklomerat, breksi, vulkanik dan tufa, unit lahan di formasi ini didominasi oleh perbukitan terdenudasi.

Sebaran batuan lepas juga dapat digunakan untuk mengindikasikan suatu lahan mengalami kerusakan atau tidak. Besar kecilnya sebaran batuan lepas yang terdapat di permukaan lahan dapat menunjukkan apakah lahan mengalami kekritisan atau tidak (Arsyad, 2006; Utomo, 1987). Sebaran batuan lepas pada setiap satuan bentuklahan menunjukkan lokasi penelitian relatif kritis, yaitu dari 32 satuan bentuklahan $75,36 \%$ berada pada 
kriteria kritis. Kondisi tersebut, tidak terlepas dari keberadaan vegetasi penutup lahan yang cukup mendukung/melindungi permukaan lahan. Secara teoritis ada hubungan ynag signifikan antara sebaran batuan lepas dengan vegetasi penutup lahan.

Hasil penelitian mengambarkan bahwa vegetasi penutup lahan di daerah penelitian dalam kondisi sedang, yaitu dari 32 satuan bentuklahan yang diteliti persentase lahan terbuka (tanpa penutup vegetasi) relatif kecil yakni hanya $72 \%$. Selebihnya tertutup oleh vegetasi tanaman sepanjang tahun, baik musim penghujan maupun musim kemarau. Oleh karena itu, kondisi bentanglahan di daerah penelitian selalu tampak menghijau sepanjang tahun. Semua satuan bentuklahan berada dalam kondisi tertutup vegetasi dengan baik.

\section{Kesimpulan}

Berdasarkan penelitian tentang kerusakan lahan yang telah dilakukan pada wilayah DAS Kreo Kota Semarang dan sekitarnya dapat disimpulkan sebagai berikut: Pertama, terjadinya perubahan penggunaan lahan di sekitar DAS Kreo dari Tahun 1995-2018 dimana terjadi peningkatan luas pemukiman dan kebun campuran serta pengurangan lahan terbuka hijau di wilayah penelitian. Kedua, faktor manusia (perkembangan pemukiman) menyebabkan terjadinya kerusakan lahan di wilayah penelitian. Faktor alami terutama geofisik lahan yang memiliki sifat kerentanan tinggi terhadap erosi dan longsor lahan. Serta kondisi topografi yang berbukit bergunung, dengan variasi kemiringan lereng menyebabkan pembangunan pemukiman lebih berdampak terhadap kondisi DAS Kreo.
Ketiga, pembangunan Waduk Jatibarang pada daerah tersebut memberikan pengaruh besar terhadap kerusakan lahan karena harus membuka lahan yang sebelumnya adalah vegetasi berupa hutan.

Berdasarkan hasil penelitian dan pembahasan penelitian beberapa saran yang bisa diajukan adalah sebagai berikut. Pertama, bagi pemerintah melakukan sosialisasi kepada masyarakat untuk lebih tanggap dalam mengelola lahan. Kedua, penerapan kaedah konservasi tanah dan air dalam setiap pelaksanaan budidaya pertanian merupakan upaya yang harus dilakukan guna mengendalikan kerusakan lahan, seperti pengendalian erosi dan longsor, dan penambahan masukan unsur hara guna menjaga kestabilan tanah. Terakhir, diperlukan ketegasan dan konsistensi pihak pemangku kebijakan dalam menerapkan regulasi yang telah ditetapkan.

\section{Daftar Pustaka}

Anggara, Bagus Budi. 2008. Kapasitas Infiltrasi Pada Penggunaan Lahan Hutan dan Sawah Sub DAS Kreo - DAS Garang Jawa Tengah. Skripsi. Semarang. Fakultas IImu Sosial.

Arikunto, Suharsimi. 2006. Prosedur Penelitian Suatu Pendekatan Praktik. Jakarta: Rineka Cipta.

Asdak, Chay. 2007. Hidrologi dan Pengelolaan Daerah Aliran Sungai.

Fauzi, Rifki Muhammad Zulfa. 2013. Prediksi Erosi Dan Sedimentasi DAS Kreo Hulu. Skripsi. Semarang. Fakultas IImu Sosial.

Sartohadi, J. 2005. "Studi Penataan DAS Sungai Serang di Kabupaten Kulonprogo" Laporan Penelitian. Kerjasama dengan Direktorat Jendral SDA dan Pt. Puser Bumi Consultants. Yogyakarta. 
Setyowati, Dewi Liesnoor. 2010. Buku Ajar Pengelolaan Daerah Aliran Sungai. Semarang: CV. Sanggar Krida Aditama.

-------. 2010b. Hubungan hujan dan limpasan pada berbagai dinamika spasial penggunaan lahan di DAS Kreo Jawa Tengah. Disertasi. Fakultas Geografi UGM. Yogyakarta

Sitorus, Santan R.P. (1985). Evaluasi Sumberdaya Lahan. PT. Tarsito, Bandung.

Soemarwoto, O. 1987. Ekologi, Lingkungan Hidup dan Pembangunan. Jakarta: Penerbit Djambatan.

Suroso. 2006. Diktat Kuliah Pengelolaan DAS. Semarang: Fakultas IImu Sosial UNNES.

Tika, Moh. Pabundu. 2005. Metode Penelitian Geografi. Jakarta: Bumi Aksara.

Triatmodjo, Bambang. 2008. Hidrologi Terapan. Beta Offset, Yogyakarta.

Tjahjono, Heri. 2005. Diktat Kuliah Geografi Tanah. Semarang: Fakultas IImu Sosial UNNES.

Utomo, Wani Hadi. 1987. Erosi dan Konservasi Tanah. Communication Soil Science UNIBRAW No. 23. Universitas Brawijaya Malang.

Verstappen, H.Th and R.A. Van Zuidam, 1968. ITC System of Geomorphological Survey. ITC. Texbook of Photo-Interpretation, Vol. VII, Enschele, The Netherlands. 